\title{
Research on Career Planning Curriculum System under the Background of Applied Transformation in Private Universities
}

\author{
Jie Jiang \\ Student potential Development Center Xi'an Peihua University \\ Xi 'an, shaanxi province
}

Keyword: Career planning; Employment Guidance; College Student

\begin{abstract}
In order to improve the quality of personnel training, enhance the comprehensive quality of students, and enhance the employability of college students to meet the requirements of employers, the career planning education of college students needs to be changed qualitatively. Career planning education itself has been unable to meet the needs of colleges and students at this stage, this paper based on the existing career planning education problems and status quo research, explore solutions to build a scientific and effective career planning curriculum system for research and discussion.

Under the background of the transformation of private colleges and universities to application-oriented, the traditional career planning education can not meet the needs of the present stage. For private colleges and universities, it is necessary to construct a new curriculum system of College Students'career planning in accordance with students' own characteristics, so that college students'career planning education is no longer formalized. Pay attention to the effectiveness and accuracy of curriculum implementation, strengthen the scientific and professional vocational planning education, improve the existing problems in private colleges and universities in career planning education, and build a scientific curriculum system.
\end{abstract}

\section{Research purpose and significance}

To strengthen the research on the curriculum system of College Students'career planning is of great importance to the application-oriented transformation and development of private colleges and universities.

Private colleges and universities to the application-oriented transformation, personnel training must be market-oriented, and the market to achieve seamless docking. Combining with the characteristics of private college students, establishing a scientific, systematic and accurate career planning curriculum system and strengthening the pace of applied curriculum reform are very important to enhance the comprehensive employment competitiveness of College students, to a large extent, affecting the quality of graduates'employment, and also directly affecting the application-oriented transformation and development of private colleges and universities.

A thorough summary of the construction of career planning courses for college students will help them to plan their study and life reasonably, enhance their employment competitiveness, and ultimately improve their employment rate and quality.

Nowadays, the number of college graduates is increasing, and social development urgently needs talents with comprehensive ability. Therefore, career planning is particularly important for college students to have the goal of learning and improve the competitiveness of employment. Private colleges and universities should help college students learn to recognize themselves objectively, understand the working world and carry out career planning rationally through systematic career planning education. The systematic curriculum system of career planning is helpful for college students to study scientifically and effectively, and then to enhance students'comprehensive professional quality and professional ability, so as to lay a solid foundation for students to enter the society. 


\section{The status quo and problems of career planning curriculum}

Status quo of career planning curriculum in private universities 。In recent years, the state has paid full attention to the career planning education for college students, requiring that the career planning education curriculum be included in the teaching plan. However, as a private university, because there are differences in school-running system, management mode and public universities, private colleges and universities do not attach relative importance to career planning education which needs long-term investment. Many colleges and universities still limit career planning courses to senior career guidance courses, or give several lectures. The content of this aspect tends to be formalized in the education system, which has little practical effect on students and schools. Secondly, as students in private colleges, they are relatively lack of initiative in learning, attention to career planning, and their comprehensive quality. Therefore, they need more suitable methods to carry out career planning education.

Problems of career planning curriculum in private universities First, curriculum construction lacks systematicness. Many school career planning courses only educate freshmen about relevant knowledge, or only give presentations on job interview skills before graduation. Career planning education activities are also basic in the lower grade students to participate in, to the higher grade stage, the students to carry out career planning education is basically no, students in the first stage through learning to know the importance of career planning for themselves, but want to continue the following steps There was no special channel to help. Therefore, career planning education is not a whole process, the lack of systematic, career planning curriculum in the form, does not play its due role.

Second, the working world lacks knowledge and the teaching mode is relatively simple. In the actual teaching of career planning, career planning teachers teach theoretical knowledge as the main content, students feel boring and lack of learning initiative. The single teaching mode makes the teacher can not mobilize the enthusiasm of students very well, the degree of participation is not high, and the learning effect is not good. Moreover, the limitations of the working environment of career planning teachers themselves can not fully understand the actual working environment of students entering the society and the different requirements of various posts on students'abilities, which affects the actual teaching effect.

Third, there is no tracking of the effect of career planning education. At the end of the course, whether the students have made career planning, how much career planning can help college students, and how to solve the problems in career planning have not been followed up, which makes many students put forward that they have paid more attention to it through the course. Starting to plan their own career, but there are many situations can not be feedback, the students'career planning education system has not been extended.

\section{Construction of career planning curriculum system under the transformation of Private Universities}

According to the actual situation of private colleges and universities, in order to better carry out the application-oriented reform and give full play to the positive role of career planning curriculum in guiding college students to plan their life reasonably, recognize themselves, and have the goal of dynamic learning, we need to establish a career planning curriculum system suitable for the development of private colleges and universities.

The whole course of career planning education is comprehensive. Career planning curriculum system should run through the whole process of the university, and include "career planning - Career Guidance - career experience education" as one of the teaching content. The freshmen and sophomores help students understand themselves, explore the working world, and master the methods of career planning. Junior college should conduct career guidance education on resume production, job interview skills and relevant laws and regulations. At the same time, senior three and four stages of career experience education, students are required to participate in profit-making organizational experience, participate in job fairs, interviews as a compulsory part of 
the practical experience of credit, on the basis of a certain theoretical knowledge, to actually experience the process of job hunting, urge each student to take the initiative to apply for a job. In addition, the whole-process education must include the career planning education for freshmen when they enter the university, so that students can understand the major they have studied, the relevant occupational fields and how to carry out college life and learning with goals.

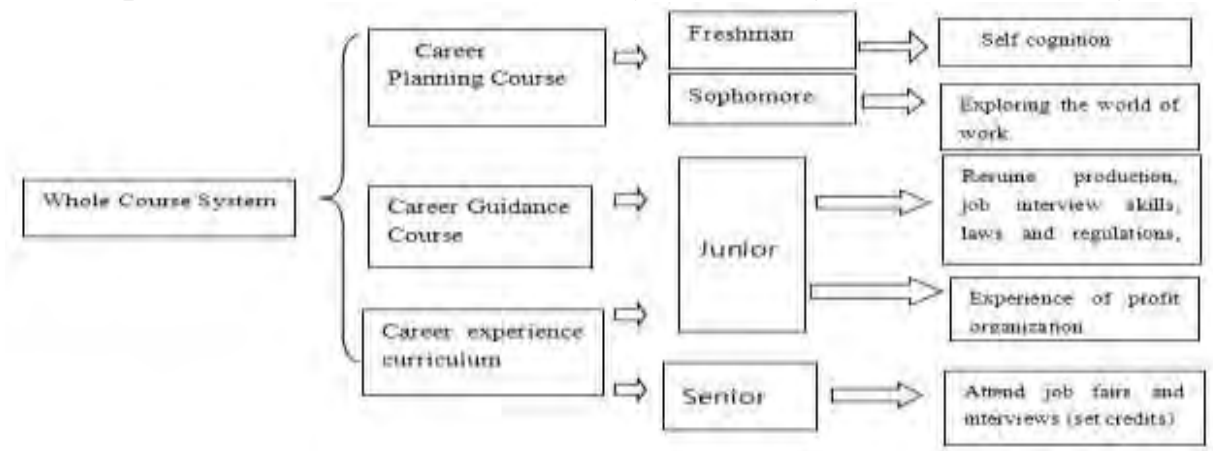

Figure 1

Improving career planning curriculum model. Classroom teaching should not be purely theoretical education. It can carry out case discussion, group career activities, practical simulation and so on. Students can actually participate in the classroom. Group career activities and experiential education can fully mobilize students'enthusiasm for learning. Classroom changes from paying attention to teachers to paying attention to students and improving students' willingness to study actively. Knowledge.

Career planning curriculum should also form a "career planning teachers - professional mentors business experts" as one of the teaching model. Second-level colleges are equipped with subject leaders and professional teachers to become professional tutors to help students understand the field of employment, working environment, business needs and so on. Professional tutors themselves have sufficient professional knowledge, to help students understand the professional content, employment and other fields will be more experienced and convincing. Also can invite human resources, market and other relevant departments of enterprise personnel as students'after-school tutors, from the enterprise point of view to explain to students the needs of the enterprise and the specific post required to have professional qualities. This Trinity education model can more effectively cultivate college students'professional quality, employment ability, practical experience, improve the comprehensive quality of College students, to achieve the best results of the curriculum.

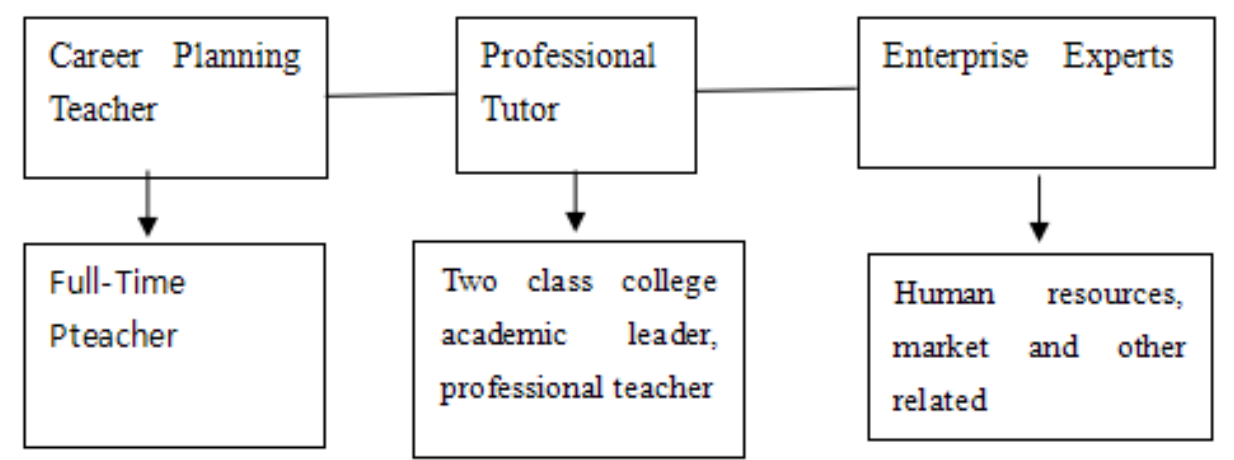

Figure 2

Based on the training of applied talents, we should establish a practical system of career planning education. As a private university, the main goal of running a school is to cultivate talents needed by enterprises, which is in line with the needs of the construction of applied universities. Then in the second classroom to carry out more practical content, to consolidate the teaching content, help students to explore the working world, improve the competitiveness of students have a great help. For example, organize student interviews, invite enterprise experts to come to school for special lectures or salon activities, organize career planning competitions and other forms of 
activities to stimulate students'interest in learning, improve students' comprehensive ability.

In addition, in order to realize the zero distance experience between students and enterprises, we can build a practice platform corresponding to students'major. We can realize the cooperation with enterprises through the secondary college as the carrier, and also strengthen the school-enterprise cooperation mode through the school level. Establish a long-term relationship with the relevant units, make full use of the enterprises or units that establish cooperative relations to carry out students'actual visits and exchanges, interviews with career figures or transport students into actual jobs, so that students can experience the work content, understand the professional environment, and know the needs of social talents to have the ability to enable teaching. Better combination of learning and practice to achieve the purpose of teaching.

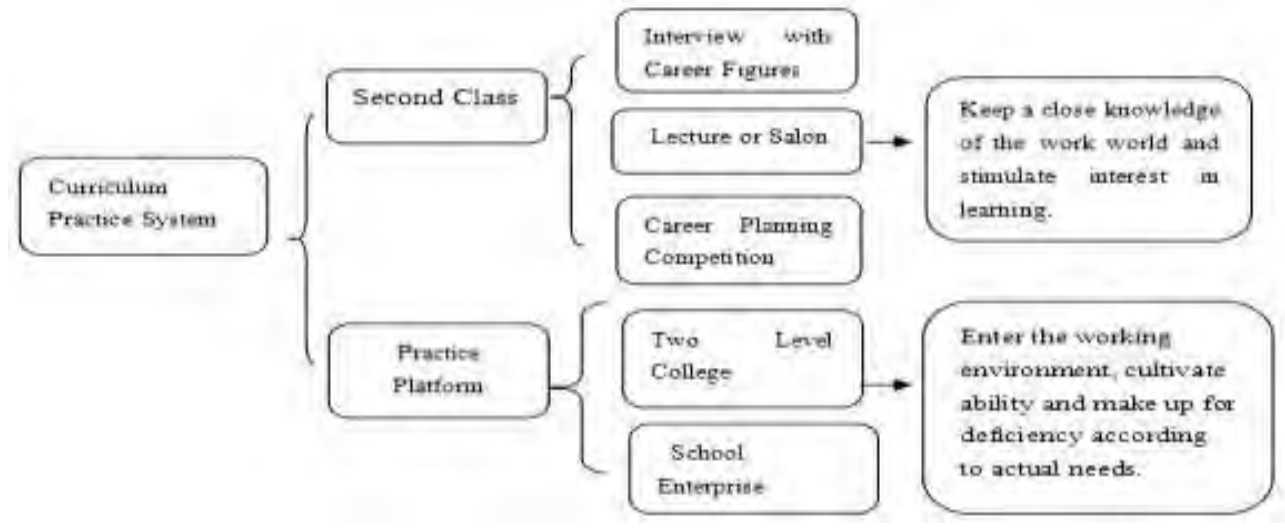

Figure 3

\section{Conclusion}

Tracking and evaluating curriculum education is indispensable, which is also an important means to implement career planning education. It is very necessary to set up the College Students'Career Planning Archives during the period of the students' university. It is necessary to set up individual career planning archives for each student based on the class as a unit, keep track of the progress and completion of the students'career planning at any time, and help students record their own self-exploration content from the beginning of the class. The completion of each stage of the target, problems, target assessment and adjustment and so on. Teachers follow up the problems in the student files according to the situation, and if there is a need for guidance or consultation, guide students to solve problems, adjust or improve their goals or plans with the help of teachers in charge of career guidance in secondary colleges or schools.

\section{Reference}

[1] The Necessity and Measures of Career Planning Education for College Students in Dongjiang. Education and Vocational, 2010, (2)

[2] Y.C.Li. Thoughts on Career planning of Chinese College Students [J]. Jiangsu higher education, 2011, (1)

[3] P.Huang . Current Situation and Countermeasures of Career Planning Education for Private College Students [J].China Youth Research, 2014, (7)

[4] D.Yang; "Empirical Study on the Teaching Effect of Career Planning for College Students" Taking Guangdong Institute of Petroleum and Chemical Industry as an Example [J]; Southern Journal;2012

[5] M.Hu. Exploration of Effective Ways to Career Planning for College Students [J]; Journal of Chifeng University (Natural Science Edition); No. 19, 2014

[6] C.W.Yu Strategic Research on Improving the Effectiveness of College Career Guidance; [J]; Journal of Henan Institute of Science and Technology; 10 issue in 2013 